OPEN ACCESS

Edited by:

Craig Stephen Moore,

Memorial University of

Newfoundland, Canada

Reviewed by:

Bradley Kerr

University of Alberta, Canada

Nader Ghasemlou,

Queen's University, Canada

*Correspondence:

Cheryl L. Stucky

cstucky@mcw.edu

Specialty section:

This article was submitted to

Multiple Sclerosis and

Neuroimmunology,

a section of the journal

Frontiers in Neurology

Received: 29 March 2019

Accepted: 28 May 2019

Published: 12 June 2019

Citation:

Cowie AM, Dittel BN and Stucky CL (2019) A Novel Sex-Dependent Target

for the Treatment of Postoperative

Pain: The NLRP3 Inflammasome.

Front. Neurol. 10:622.

doi: 10.3389/fneur.2019.00622

\section{A Novel Sex-Dependent Target for the Treatment of Postoperative Pain: The NLRP3 Inflammasome}

\author{
Ashley M. Cowie ${ }^{1}$, Bonnie N. Dittel ${ }^{2,3}$ and Cheryl L. Stucky ${ }^{1 *}$ \\ ${ }^{1}$ Department of Cell Biology, Neurobiology, and Anatomy, Medical College of Wisconsin, Milwaukee, WI, United States, \\ ${ }^{2}$ Blood Research Institute, Versiti, Milwaukee, WI, United States, ${ }^{3}$ Department of Microbiology and Immunology, Medical \\ College of Wisconsin, Milwaukee, WI, United States
}

In recent years the innate immune system has been shown to be crucial for the pathogenesis of postoperative pain. The mediators released by innate immune cells drive the sensitization of sensory neurons following injury by directly acting on peripheral nerve terminals at the injury site. The predominate sensitization signaling pathway involves the proinflammatory cytokine interleukin-1 $\beta(\mathrm{IL}-1 \beta) . \mathrm{IL}-1 \beta$ is known to cause pain by directly acting on sensory neurons. Evidence demonstrates that blockade of $\mathrm{IL}-1 \beta$ signaling decreases postoperative pain, however complete blockade of IL-1 $1 \beta$ signaling increases the risk of infection and decreases effective wound healing. IL-1 $\beta$ requires activation by an inflammasome; inflammasomes are cytosolic receptors of the innate immune system. NOD-like receptor protein 3 (NLRP3) is the predominant inflammasome activated by endogenous molecules that are released by tissue injury such as that which occurs during neuropathic and inflammatory pain disorders. Given that selective inhibition of NLRP3 alleviates postoperative mechanical pain, its selective targeting may be a novel and effective strategy for the treatment of pain that would avoid complications of global IL-1 $\beta$ inhibition. Moreover, NLRP3 is activated in pain in a sex-dependent and cell type-dependent manner. Sex differences in the innate immune system have been shown to drive pain and sensitization through different mechanisms in inflammatory and neuropathic pain disorders, indicating that it is imperative that both sexes are studied when researchers investigate and identify new targets for pain therapeutics. This review will highlight the roles of the innate immune response, the NLRP3 inflammasome, and sex differences in neuropathic and inflammatory pain.

Keywords: NLRP3, interleukin-1 $1 \beta$, sex differences, pain, tissue injury, innate immunity

\section{INTRODUCTION}

A unique combination of molecular and cellular factors can lead to acute and chronic pain conditions with varying pathologies. Despite this, pain is categorized into the following broad categories: inflammatory, neuropathic, and syndrome-based (e.g., fibromyalgia). There is overlap between these generalized categories. For example, inflammation can result in nerve damage, nerve injury involves inflammation, and syndrome-based pain can be neuropathic or inflammatory or both. Inflammatory pain occurs with 
peripheral tissue damage and the resulting tissue inflammation. Alternatively, neuropathic pain results from direct damage to nerves in the peripheral or central nervous systems. Postoperative pain has both inflammatory and neuropathic qualities (1). It is widely recognized that postoperative pain occurs as a result of the direct cutting of tissues and peripheral nerves at the surgical site.

Rodent models of postoperative pain have been consistently used to study the underlying causes of postoperative pain. Rodent models of surgical pain are strong preclinical models because the injury induced in the animal and human is similar, and therefore, these models likely recapitulate patient phenotypes and mechanisms (1-3). The most common postoperative pain model involves cutting through the skin and underlying muscle (flexor digitorum brevis), which reliably produces mechanical and heat hyperalgesia at the incision site (4-9). There is a robust immune response in this model that includes infiltration of neutrophils, macrophages, and lymphocytes. The immune response aids in wound healing, but also results in sensitization of sensory neurons to mechanical and heat stimuli $(1,10-13)$. The immune response begins at the incision site or site of tissue damage and moves proximally to the dorsal root ganglia and spinal cord.

There is a rapidly growing body of evidence demonstrating that the development and maintenance of postoperative pain are not solely dependent on the increased excitability of sensory neurons alone at the incision site, but they also depend on immune cell interactions with sensory neurons and activation of canonical immune receptors expressed by sensory neurons. Components of the innate immune system have emerged as crucial mediators in the development and maintenance of hypersensitivity following incision. Pattern-recognition receptors (PRRs) are part of the innate immune system and are among the first to be activated in response to tissue damage; their activation is important for the induction of immune responses leading to pathogen elimination and subsequent tissue repair (14). PRRs include cytosolic NOD-like receptors (NLRs) which, when activated, form inflammasomes. The NLR protein 3 (NLRP3) inflammasome is the best characterized NLR and has been shown to be critical in driving the immune response to sterile tissue damage (15), the type of inflammation that occurs with surgical incision. Additionally, NLRP3 is known to play a role in several painful conditions that arise from sterile tissue damage (16-30). Since the immune system is known to be sexually dimorphic, much recent attention has been given to understanding the sex differences and their causative factors that underlie painful conditions. However, little is known about the effects of sex on NLRP3 or the role of NLRP3 in postoperative pain. Therefore, this review provides a new insight into the relationship between NLRP3 and postoperative pain. Here we discuss the current understanding of sexual dimorphism in the innate immune system response to tissue injury and the role it plays in inflammatory and neuropathic pain conditions by focusing on the NLRP3 inflammasome.

\section{THE IMMUNE RESPONSE TO INCISIONAL INJURY}

\section{Immune Cell Involvement}

Surgical incision results in local tissue injury, which destroys physical barriers between the body and environment, and increases the risk of exposure to environmental and commensal microbes. These consequences of surgery all lead to activation of the innate immune system and local inflammation. Inflammation occurs immediately following tissue injury as an attempt to clear debris and initiate healing. Initially immune cells such as mast cells, neutrophils, and monocytes/macrophages are recruited to the injury site by mediators that are released in tissues, by neurons and by tissue-resident immune cells (12, 3134). Recruitment and activation of different immune cells following injury occurs in the same sequence in both sexes. First, dermal mast cells regulate inflammation immediately following cutaneous wounding by releasing inflammatory mediators, thereby increasing vascular permeability and recruiting neutrophils $(35,36)$. The neutrophil recruitment is generally followed by monocyte/macrophage recruitment, which occurs 1-2 days following injury $(12,34,37,38)$. Macrophages play a dual role in wound healing, where initially they promote inflammation and then later, they switch to a reverse role where they promote the resolution of inflammation (34). Lastly, during the resolution of inflammation phase, $T$ cells infiltrate the wound to aid in healing $(34,39)$.

\section{The NLRP3 Inflammasome and Interleukin-1 $\beta$ Production}

Surgical trauma is aseptic and causes the release of damageassociated molecular patterns (DAMPs) (40). DAMPs are endogenous molecules that are released from damaged or dying cells and serve as a signal for tissue damage (41). Soluble DAMPs that are released as a result of incision include: heparan sulfate $(42,43)$, fibronectin $(44,45)$, hyaluronan $(46-48), \beta$-defensins (49-51), heat shock protein 70 (Hsp70) (52), and high mobility group box-1 (HMGB1) $(53,54)$. These DAMPs then bind to PRRs such as Toll-like Receptors (TLRs) on innate immune cells (mast cells, neutrophils, monocytes/macrophages) and sensory neurons, specifically Toll-like Receptor 4 (TLR4) (18, 49, 55-58). Stimulation of TLR4 leads to activation of the transcription factor $\mathrm{NF}-\kappa \mathrm{B}$ and upregulation of the synthesis of pro-inflammatory cytokines like interleukin-1 $\beta$ (IL-1 $\beta$ ) (59). Stimulation of TLR4 also serves as the priming signal for NLRP3, the activator of IL-1 $\beta$ (59).

NLRP3 is predominately expressed by cells in lymphoid organs and tissues that are highly populated by immune cells. These cells include but are not limited to mast cells, neutrophils, macrophages, monocytes, dendritic cells, and neurons in both the peripheral and central nervous systems (29, 60-62). The expression of NLRP3 in these cell types must be induced by inflammatory stimuli, which prevents uncontrolled release of IL-1 $\beta$. NLRP3 requires two signals for canonical activation and for IL-1 $\beta$ secretion: the first signal primes the cell to express NLRP3 and pro-IL-1 $\beta$, and the second signal induces inflammasome assembly and activation $(41,63,64)$. NLRP3 
forms a scaffold with apoptosis-associated speck-like protein containing a CARD (ASC) to provide a molecular platform for activation of pro-caspase-1, which collectively comprises the inflammasome (65). Activated caspase-1 cleaves pro-IL$1 \beta$ into active IL- $1 \beta$, which is secreted. Several DAMPs that are present after incision and that can serve as the activation signal for NLRP3 inflammasome assembly include: ATP $(66,67)$, reactive oxygen species (ROS) $(68,69)$, and low $\mathrm{pH}(70-72)$. The activation cascade for NLRP3 is summarized in Figure 1. Indeed, the presence of priming and activating DAMPs for NLRP3 activation after aseptic tissue injury implicate a role for NLRP3 in mediating the postoperative pain phenotype. We recently showed that NLRP3 is upregulated at the surgical site and drives postoperative mechanical pain-like behaviors in male mice, but not in female mice (13). This study provided the first evidence that NLRP3 drives postoperative pain and revealed that the immune-mediated mechanisms that underlie postoperative pain are sex-specific.

\section{SEXUAL DIMORPHISM IN THE IMMUNE RESPONSE}

The importance of taking sex into consideration when studying painful injuries and their underlying mechanisms was recently highlighted when it was revealed by Sorge et al. that male mice require microglia and TLR4, whereas female mice require $\mathrm{T}$ cells to mediate chronic neuropathic pain $(73,74)$. In addition, hormones significantly contribute to sex-based differences in the immune response (75). Estradiol, progesterone, and testosterone are the primary hormones that affect the immune response. Female vertebrates have higher baseline estrogen and progesterone levels whereas male vertebrates have higher baseline testosterone levels. Estrogen, progesterone, and testosterone receptors are expressed on both adaptive ( $T$ cells and $B$ cells) and innate (macrophages, dendritic cells, neutrophils, and natural killer cells) immune cells; the effects of hormones on these receptors are dose-dependent (76). Consequently, there are alterations in immune system function during pregnancy, menses, and menopause. Each of the three hormones mentioned above affects the immune system during injury or disease states in different ways, and therefore, the immune response to injury differs between males and females.

The level of immune cell infiltration and the extent of the innate immune response at an injury site are both affected by sex hormones. Estrogen suppresses mast cell release of histamine and as a result, fewer neutrophils are recruited to a wound site in females $(77,78)$. In regards to the effects of estrogen on the macrophage response to injury, Price et al. recently showed that a reduced number of macrophages is recruited to a postoperative tissue site in female mice compared to male mice (79). Additionally, high estrogen levels skew macrophages toward the M2 phenotype (anti-inflammatory) while high testosterone levels promote the M1 phenotype (proinflammatory). As a consequence of the M1 phenotype, males have higher expression of TLR4, NLRP3, and produce more IL-1 $\beta$ than females $(75,80-83)$. However, chronic estrogen exposure induces increased TLR4-mediated production of IL$1 \beta$ in macrophages (84). Despite the lower levels of immune cell infiltrate within a wound in females as compared to males, cytokine levels in females are sustained longer than in males, and females have more tissue-resident immune cells than males $(75,78)$. Furthermore, data from our laboratory demonstrated that males have more IL- $1 \beta$ protein at the peri-incisional site than females (13). Whereas, we showed that NLRP3 mRNA was upregulated by incision to a similar extent in males and females, global deletion of NLRP3 decreased IL- $1 \beta$ levels and sensitization to mechanical stimuli only in males. This suggested that NLRP3 may be differentially regulated post-transcriptionally in males and females following tissue incision, where in females, the IL$1 \beta$ production occurs independent of NLRP3. The activation pathway for NLRP3 has been suggested to differ in macrophages from male and female Systemic Lupus Erythematosus patients as well (85). In addition, males and females utilize TLR4 in a cell-specific manner. Stimulation of TLR4 on macrophages drives pain in male mice whereas stimulation of TLR4 on sensory neurons drives pain in female mice $(86,87)$. Furthermore, fibroblasts which play critical roles in the immune response and local environment during tissue injury, also produce IL- $1 \beta$, and fibroblast IL-1 $\beta$ levels are differentially affected by testosterone and estrogen treatment (88). Considering all of the evidence above for sex-driven differences in the immune response to injury and the resulting differences in sensory neurons, it is imperative to take the sex of an individual into account when selecting and assessing the efficacy of pain interventions.

\section{PROINFLAMMATORY IL-1 $\beta$ AND POSTOPERATIVE PAIN}

The primary function of IL- $1 \beta$ is to elicit a pro-inflammatory response to DAMPs (41). IL- $1 \beta$ is expressed by macrophages, monocytes, neutrophils, mast cells, glial cells, and sensory neurons (89-91). Secreted IL-1 $\beta$ exerts its proinflammatory effects through various mechanisms. These include increasing production of other inflammatory mediators via rapidly inducing their mRNA expression, increasing vascular permeability, recruiting immune cells, directly eliciting pain via binding of the IL-1 $\beta$ receptor on sensory neurons, and inducing neurogenic inflammation through sensory neuron sensitization and increased production of calcitonin gene-related peptide alpha (CGRP $\alpha)$ (91-94). IL-1 $\beta$ acts through its receptor type I IL1 receptor (IL-1R1), which is ubiquitously expressed on neurons of the peripheral and central nervous systems $(95,96)$. When IL-1R1 binds IL-1 $\beta$, the accessory protein IL-1R3 is recruited to induce intracellular signaling cascades via association of their intracellular Toll- and IL-1R-like (TIR) domains with signaling proteins (97). The cascade begins with the association of myeloid differentiation primary response gene 88 (MYD88) and interleukin-1 receptor-activated protein kinase (IRAK) 4 with the TIR domains. This leads to complex formation of IRAK1, IRAK2, and tumor necrosis factor-associated factor (TRAF) six and subsequent activation of transcription factors such as NF-кB to upregulate inflammatory genes. 


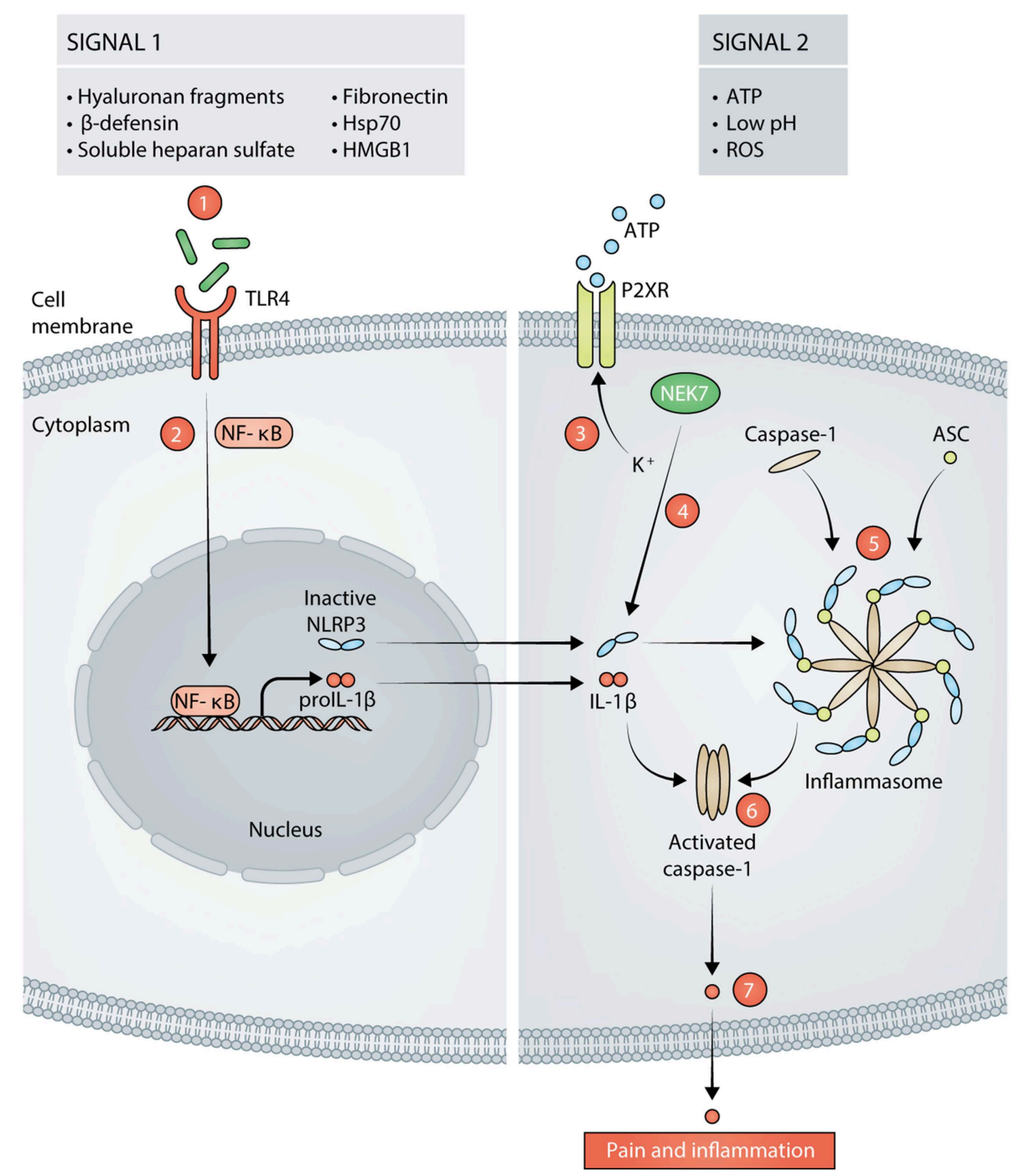

FIGURE 1 | Signals in response to tissue damage activate the NLRP3 inflammasome (signal 1 and signal 2). Hyaluronan fragments, $\beta$-defensins, soluble heparan sulfate, fibronectin, 70 kilodalton heat shock proteins (Hsp70), and high mobility group box 1 (HMGB1) are released following incision and act as signal 1 for NLRP3 by stimulating TLR4 on the cell membrane (1). Stimulation of TLR4 leads to activation of NF-kB and transcription of prolL-1 $\beta$ and NLRP3 (2). Adenosine Triphosphate (ATP), reactive oxygen species (ROS), and low pH can then act as signal 2 for NLRP3. ATP acts on purinergic ion channel receptors (P2XR) such as P2X7 or P2X4 which results in potassium $\left(\mathrm{K}^{+}\right)$efflux from the cell (3). The decrease in $\mathrm{K}^{+}$concentration is sensed by NIMA Related Kinase 7 (NEK7). NEK7 associates with inactive NLRP3, thereby activating it (4). Active NLRP3 then forms a scaffold with caspase-1 and apoptosis-associated speck-like protein containing a CARD (ASC), thus, forming the inflammasome (5). Caspase- 1 is activated by the formation of the inflammasome (6). Activated caspase- 1 cleaves prolL- into mature IL-1 $\beta$ that is released from the cell and subsequently, results in pain and inflammation (7).

Postoperative pain is characterized by persistent acute pain at the incisional site which is associated with release of proinflammatory cytokines, including IL-1 $\beta$. Studies have found that IL- $1 \beta$ is significantly upregulated at the incision site (12, $13,32,98-101)$. Wolf et al. demonstrated that either systemic inhibition of IL-1 $\beta$ signaling by its receptor antagonist IL-1ra or deletion of IL-1R1 prevented the development and maintenance of postoperative mechanical hypersensitivity at the incision site (102). Other groups further demonstrated that inhibition of IL$1 \beta$ signaling through antagonism of its receptor significantly decreased postoperative pain-like behavior in rodents $(32,98$, 100). Furthermore, additional research has established that inhibition of the upstream mediators of IL-1 $\beta$, such as TLR4 (98, 103), NF-KB (103), caspase-1 (104), or NLRP3 (13), decreases postoperative pain-like behaviors in rodents. General blockade of IL-1 $\beta$ signaling, like that obtained with FDA approved Anakinra (IL-1R1 antagonist), increases the rate of infections due to the necessity of IL-1 $\beta$ for bacterial infection clearance $(105,106)$. Whereas, inhibition of TLR4, NF- $\kappa \mathrm{B}$, and caspase- 1 is more ubiquitous, inhibition of one inflammasome is more specific. Therefore, reduction of IL-1 $\beta$ but not complete depletion, through inhibition of only NLRP3 may avoid these complications while decreasing postoperative pain. However, inhibition of NLRP3 alone may only be effective in males but not females 
(13). Not only are sex differences prevalent in mice that received surgery, but they are present in human postoperative pain as well. For instance, a predicative factor of chronic postoperative pain is female sex (107-109). Thus, a therapeutic for the treatment of postoperative pain in females must target the unique factors that are required for the development of postoperative pain in females.

\section{THE ROLE OF NLRP3 IN PAIN DISORDERS}

Much is yet to be learned about NLRP3 and postoperative pain, however a role for NLRP3 in pain disorders is emerging (13). NLRP3 has been shown to be involved in the pathogenesis of both inflammatory and neuropathic pain conditions. Inflammatory pain depends on the sensitization of nociceptive neurons by proinflammatory mediators such as IL- $1 \beta(110,111)$. In an acute model of dural inflammation, the injection of an "inflammatory soup" (comprised of histamine, serotonin, bradykinin, and prostaglandin $\mathrm{E} 2$ at $\mathrm{pH} 5.5$ ) resulted in activated NLRP3 and caspase- 1 , and increased IL- $1 \beta$ expression in C fiber type neurons of the trigeminal ganglia (29). The inflammatory soup injection also resulted in pain-like behaviors which were alleviated by a caspase-1 inhibitor. In another inflammatory pain model, the complete Freund's adjuvant (CFA) model, NLRP3 was shown to be activated in the skin of rats (28). Electroacupuncture following CFA injection attenuated the expression of NLRP3 and ultimately eliminated the pain-like behavior (28). Additionally, NLRP3 has been demonstrated to be crucial for the pathogenesis of rheumatoid arthritis in both humans and rodents (27, 112, 113). Further, upregulation of NLRP3 has been shown to occur in rodent models of gout, and its inhibition or deletion ameliorated the pathology and pain $(24,25,114-$ 116). Collectively, these data point to a key role for NLRP3 in inflammatory pain.

Neuropathic pain involves direct damage to nerves from injury or disease. IL-1 $\beta$ significantly contributes to traumatic neuropathic pain where its expression is upregulated in the dorsal root ganglia and spinal cord, as well as in damaged nerves in rodent models of neuropathic pain and in patients with neuropathic pain $(18,117-119)$. NLRP3 plays a role in various rodent models of neuropathic pain. Alleviation of sciatic nerve ligation neuropathic pain with miR-23a overexpression, or CXCR4 knockdown results in decreased NLRP3 expression (16). A study utilizing the chronic constriction sciatic nerve injury model of neuropathic pain demonstrated that NLRP3 is upregulated by nerve injury and that treatment with Peptide5, a Connexin 43 mimetic peptide that blocks hemichannels, decreased NLRP3 expression and mechanical pain-like behavior (17). In addition, chemotherapy-induced neuropathy models of neuropathic pain revealed that NLRP3 is upregulated in both oxaliplatin-induced nerve injury (19) and paclitaxelinduced nerve injury (20) models, and inhibition of NLRP3 decreased the mechanical pain-like behaviors in both models. In contrast to these findings, it was demonstrated that global knockout of NLRP3 had no effect on neuropathic pain in the spared nerve injury model of neuropathic pain (120). This is consistent with discrepant findings that challenge the view that microglia drive neuropathic pain exclusively in males (121-123). When compared, these studies demonstrate that different models of neuropathic pain (spared nerve injury, spinal nerve transection, spinal nerve ligation, and partial nerve ligation) do not produce the same findings. Together, these studies suggest that while NLRP3 contributes to a variety of etiologies of neuropathic pain it is dependent on the type of injury and the diverse factors that are likely involved in different injuries.

Although much remains to be discovered about the mechanistic causes of body-wide pain syndromes such as fibromyalgia, several studies have indicated a role for NLRP3 in fibromyalgia-associated pain, and NLRP3 was found to be upregulated in patients with fibromyalgia (21-23). Further research is needed in animal models of fibromyalgia and tissues from patients with fibromyalgia.

\section{CONCLUSION}

The discovery of inflammasomes has provided new insights into the molecular mechanisms underlying the innate immune system activation in inflammatory and neuropathic pain conditions. As discussed here, many inflammatory and neuropathic pain conditions, and specifically postoperative pain, involve the innate immune system and NLRP3. Therefore, modulators of NLRP3 may provide a novel, selective, and effective pain therapeutic target. Notwithstanding, our understanding of the functional roles and the mechanisms of activation of the NLRP3 inflammasome in pain conditions is in its infancy. Additionally, it is imperative that further research be conducted on the effect of the sex of an individual on NLRP3 function since all of the rodent studies on NLRP3 in the pain conditions discussed here, except for the report by our group (13), were performed in males only. In our study we revealed that there are significant sex differences when NLRP3 is deleted, suggesting that NLRP3 plays different roles in males and females following tissue injury (13). Additionally, the literature concerning the specific immune responses to perioperative incision in males and females is insufficient and far more studies that include females must be done. Therefore, we conclude that targeting NLRP3 may provide a novel approach to control pain, but that further research needs to uncover the mechanistic differences and roles of NLRP3 in wound healing following surgery in females and males.

\section{DATA AVAILABILITY}

No datasets were generated or analyzed for this study.

\section{AUTHOR CONTRIBUTIONS}

AMC wrote and edited the manuscript. CLS and BND edited the manuscript. 


\section{FUNDING}

This work was supported by the National Institute of Neurological Disorders and Stroke grants NS040538 and NS070711 to CLS and F31GM123778 to AMC. The Research and Education Component of the Advancing a Healthier Wisconsin Endowment

\section{REFERENCES}

1. Pogatzki-Zahn EM, Segelcke D, Schug SA. Postoperative pain-from mechanisms to treatment. PAIN Rep. (2017) 2:e588. doi: 10.1097/PR9.0000000000000588

2. Brennan TJ. Pathophysiology of postoperative pain. Pain. (2011) 152:S3340. doi: 10.1016/j.pain.2010.11.005

3. Mogil JS. Animal models of pain: progress and challenges. Nat Rev Neurosci. (2009) 10:283-94. doi: 10.1038/nrn2606

4. Barabas ME, Stucky CL. TRPV1, but not TRPA1, in primary sensory neurons contributes to cutaneous incision-mediated hypersensitivity. Mol Pain. (2013) 9:1-14. doi: 10.1186/1744-8069-9-9

5. Zahn PK, Brennan TJ. Primary and secondary hyperalgesia in a rat model for human postoperative pain. Anesthesiology. (1999) 90:863-872.

6. Cowie AM, Moehring F, O'Hara C, Stucky CL. Optogenetic inhibition of CGRP $\alpha$ sensory neurons reveals their distinct roles in neuropathic and incisional pain. J Neurosci. (2018) 38:5807-25. doi: 10.1523/JNEUROSCI.3565-17.2018

7. Brennan TJ, Vandermeulen EP, Gebhart GF. Characterization of a rat model of incisional pain. Pain. (1996) 64:493501. doi: 10.1016/0304-3959(95)01441-1

8. Pogatzki EM, Raja SN. A mouse model of incisional pain. Anesthesiology. (2003) 99:1023-7. doi: 10.1097/00000542-200310000-00041

9. Cowie AM, Stucky CL. A mouse model of postoperative pain. Bio Protocol. (2019) 9:3140. doi: 10.21769/BioProtoc.3140

10. Raoof R, Willemen HLD, Eijkelkamp N. Divergent roles of immune cells and their mediators in pain. Rheumatology. (2018) 57:429-40. doi: 10.1093/rheumatology/kex308

11. Beilin B, Shavit Y, Trabekin E, Mordashev B, Mayburd E, Zeidel A, et al. The effects of postoperative pain management on immune response to surgery. Anesth Analg. (2003) 97:822-7. doi: 10.1213/01.ANE.0000078586. $82810.3 \mathrm{~B}$

12. Ghasemlou N, Chiu IM, Julien J-P, Woolf CJ. CD11b+Ly6G- myeloid cells mediate mechanical inflammatory pain hypersensitivity. Proc Natl Acad Sci. (2015) 112:E6808-17. doi: 10.1073/pnas.1501372112

13. Cowie AM, Menzel AD, O'Hara C, Lawlor MW, Stucky CL. NOD-like receptor protein 3 inflammasome drives postoperative mechanical pain in a sex-dependent manner. Pain. (2019). doi: 10.1097/j.pain.0000000000001555. [Epub ahead of print]

14. Ye Z, Ting JPY. NLR, the nucleotide-binding domain leucinerich repeat containing gene family. Curr Opin Immunol. (2008) 20:3-9. doi: 10.1016/j.coi.2008.01.003

15. Cassel SL, Sutterwala FS. Sterile inflammatory responses mediated by the NLRP3 inflammasome. Eur J Immunol. (2010) 40:607-11. doi: 10.1002/eji.200940207

16. Pan Z, Shan $\mathrm{Q}, \mathrm{Gu} \mathrm{P}$, Wang XM, Tai LW, Sun $\mathrm{M}$, et al. miRNA23a/CXCR4 regulates neuropathic pain via directly targeting TXNIP/NLRP3 inflammasome axis. J Neuroinflammation. (2018) 15:1-19. doi: 10.1186/s12974-018-1073-0

17. Tonkin RS, Bowles C, Perera CJ, Keating BA, Makker PGS, Duffy SS, et al. Attenuation of mechanical pain hypersensitivity by treatment with Peptide5, a connexin-43 mimetic peptide, involves inhibition of NLRP3 inflammasome in nerve-injured mice. Exp Neurol. (2018) 300:112. doi: 10.1016/j.expneurol.2017.10.016

18. Grace PM, Strand KA, Galer EL, Rice KC, Maier SF, Watkins LR. Protraction of neuropathic pain by morphine is mediated by spinal damage associated molecular patterns (DAMPs) in male rats. Brain Behav Immun. (2018) 72:45-50. doi: 10.1016/j.bbi.2017.08.018 at the Medical College of Wisconsin provided partial support.

\section{ACKNOWLEDGMENTS}

The authors thank Neil Smith, freelance illustrator, for creation of Figure 1.

19. Wahlman C, Doyle TM, Little JW, Luongo L, Janes K, Chen $Z$, et al. Chemotherapy-induced pain is promoted by enhanced spinal adenosine kinase levels through astrocyte-dependent mechanisms. Pain. (2018) 159:1025-34. doi: 10.1097/j.pain.00000000000 01177

20. Jia $\mathrm{M}, \mathrm{Wu} \mathrm{C}$, Gao F, Xiang $\mathrm{H}$, Sun $\mathrm{N}$, Peng $\mathrm{P}$, et al. Activation of NLRP3 inflammasome in peripheral nerve contributes to paclitaxel-induced neuropathic pain. Mol Pain. (2017) 13:1744806917719804. doi: 10.1177/1744806917719804

21. Cordero MD, Alcocer-Gómez E, Culic O, Carrión AM, de Miguel M, Díaz-Parrado E, et al. NLRP3 inflammasome is activated in fibromyalgia: the effect of coenzyme Q10. Antioxid Redox Signal. (2014) 20:116980. doi: 10.1089/ars.2013.5198

22. Cordero MD, Alcocer-Gómez E, Marín-Aguilar F, Rybkina T, Cotán D, Pérez-Pulido A, et al. Mutation in cytochrome b gene of mitochondrial DNA in a family with fibromyalgia is associated with NLRP3-inflammasome activation. J Med Genet. (2015) 53:113-22. doi: 10.1136/jmedgenet-2015-103392

23. Bullón P, Alcocer-Gómez E, Carrión AM, Marín-Aguilar F, GarridoMaraver J, Román-Malo L, et al. AMPK phosphorylation modulates pain by activation of NLRP3 inflammasome. Antioxid Redox Signal. (2016) 24:15770. doi: 10.1089/ars.2014.6120

24. Goldberg EL, Asher JL, Molony RD, Shaw AC, Zeiss CJ, Wang C, et al $\beta$-hydroxybutyrate deactivates neutrophil NLRP3 inflammasome to relieve gout flares. Cell Rep. (2017) 18:2077-87. doi: 10.1016/j.celrep.2017.02.004

25. Liu HJ, Pan XX, Liu BQ, Gui X, Hu L, Jiang CY, et al. Grape seed-derived procyanidins alleviate gout pain via NLRP3 inflammasome suppression. J Neuroinflamm. (2017) 14:74. doi: 10.1186/s12974-017-0849-y

26. Marchetti C, Swartzwelter B, Gamboni F, Neff CP, Richter K, Azam T, et al. OLT1177, a $\beta$-sulfonyl nitrile compound, safe in humans, inhibits the NLRP3 inflammasome and reverses the metabolic cost of inflammation. Proc Natl Acad Sci USA. (2018) 115:E1530-9. doi: 10.1073/pnas. 1716095115

27. Guo C, Fu R, Wang S, Huang Y, Li X, Zhou M, et al. NLRP3 inflammasome activation contributes to the pathogenesis of rheumatoid arthritis. Clin Exp Immunol. (2018) 194:231-43. doi: 10.1111/cei.13167

28. Gao F, Xiang H-C, Li H, Jia M, Pan X, Pan H-L, et al. Electroacupuncture inhibits NLRP3 inflammasome activation through CB2 receptors in inflammatory pain. Brain Behav Immun. (2018) 67:91-100. doi: 10.1016/j.bbi.2017.08.004

29. Chen L, Li X, Huang L, Wu Q, Chen LE, Wan Q. Chemical stimulation of the intracranial dura activates NALP3 inflammasome in trigeminal ganglia neurons. Brain Res. (2014) 1566:1-11. doi: 10.1016/j.brainres.2014.04.019

30. Zhang H, Li F, Li WW, Stary C, Clark JD, Xu S, et al. The inflammasome as a target for pain therapy. Br J Anaesth. (2016) 117:693707. doi: 10.1093/bja/aew376

31. Hu Y, Liang $\mathrm{D}$, Li $\mathrm{X}$, Liu HH, Zhang $\mathrm{X}$, Zheng $\mathrm{M}$, et al. The role of interleukin-1 in wound biology. part I: murine in silico and in vitro experimental analysis. Anesth Analg. (2010) 111:152533. doi: 10.1213/ANE.0b013e3181f5ef5a

32. Hu Y, Liang $\mathrm{D}$, Li $\mathrm{X}$, Liu HH, Zhang $\mathrm{X}$, Zheng $\mathrm{M}$, et al. The role of interleukin-1 in wound biology. part II: in vivo and human translational studies. Anesth Analg. (2010) 111:153442. doi: 10.1213/ANE.0b013e3181f691eb

33. Martin P, D'Souza D, Martin J, Grose R, Cooper L, Maki R, et al. Wound healing in the PU.1 null mouse: tissue repair is not dependent on inflammatory cells. Curr Biol. (2003) 13:1122-8. doi: 10.1016/S0960-9822(03)00396-8 
34. Baum CL, Arpey CJ. Normal cutaneous wound healing: clinical correlation with cellular and molecular events. Dermatologic Surg. (2005) 31:67486. doi: 10.1097/00042728-200506000-00011

35. Nakamura Y, Kambe N, Saito M, Nishikomori R, Kim Y-G, Murakami M, et al. Mast cells mediate neutrophil recruitment and vascular leakage through the NLRP3 inflammasome in histamine-independent urticaria. J Exp Med. (2009) 206:1037-46. doi: 10.1084/jem.20082179

36. Wulff BC, Wilgus TA. Mast cell activity in the healing wound: more than meets the eye? Exp Dermatol. (2013) 22:507-10. doi: 10.1111/exd.12169

37. Delavary BM, van der Veer WM, van Egmond M, Niessen FB, Beelen RHJ. Macrophages in skin injury and repair. Immunobiology. (2011) 216:75362. doi: 10.1016/j.imbio.2011.01.001

38. Serhan CN, Savill J. Resolution of inflammation: the beginning programs the end. Nat Immunol. (2005) 6:1191-7. doi: 10.1038/ni1276

39. Larouche J, Sheoran S, Maruyama K, Martino MM. Immune regulation of skin wound healing: mechanisms and novel therapeutic targets. Adv Wound Care. (2018) 7:209-31. doi: 10.1089/wound.2017.0761

40. Zhang Q, Raoof M, Chen Y, Sumi Y, Sursal T, Junger W, et al. Circulating mitochondrial DAMPs cause inflammatory responses to injury. Nature. (2010) 464:104-7. doi: 10.1038/nature08780

41. Martinon F, Mayor A, Tschopp J. The inflammasomes: guardians of the body. Annu Rev Immunol. (2009) 27:22965. doi: 10.1146/annurev.immunol.021908.132715

42. Oksala O, Salo T, Tammi R, Häkkinen L, Jalkanen M, Inki P, et al. Expression of proteoglycans and hyaluronan during wound healing. J Histochem Cytochem. (1995) 43:125-35. doi: 10.1177/43.2.7529785

43. Johnson GB, Brunn GJ, Kodaira Y, Platt JL. Receptor-mediated monitoring of tissue well-being via detection of soluble heparan sulfate by toll-like receptor 4. J Immunol. (2002) 168:5233-9. doi: 10.4049/jimmunol.168.10.5233

44. Tscharntke M, Pofahl R, Chrostek-Grashoff A, Smyth N, Niessen C, Niemann C, et al. Impaired epidermal wound healing in vivo upon inhibition or deletion of Rac1. J Cell Sci. (2007) 120:1480-90. doi: 10.1242/jcs.03426

45. Gauperaa T, Giercksky K, Revhaug A, Rekvig O. Fibronectin, complement and immunoglobulins in serum after surgery. Br J Surg. (1985) 72:5962. doi: 10.1002/bjs. 1800720123

46. Taylor KR, Yamasaki K, Radek KA, Di Nardo A, Goodarzi H, Golenbock D, et al. Recognition of hyaluronan released in sterile injury involves a unique receptor complex dependent on toll-like receptor 4, CD44, and MD-2.J Biol Chem. (2007) 282:18265-75. doi: 10.1074/jbc.M606352200

47. Litwiniuk M, Krejner A, Grzela T. Hyaluronic acid in inflammation and tissue regeneration. Wounds. (2016) 28:78-88

48. Maharjan AS, Pilling D, Gomer RH. High and low molecular weight hyaluronic acid differentially regulate human fibrocyte differentiation. PLoS ONE. (2011) 6:e26078. doi: 10.1371/journal.pone.0026078

49. Gariboldi S, Palazzo M, Zanobbio L, Selleri S, Sommariva M, Sfondrini L, et al. Low molecular weight hyaluronic acid increases the selfdefense of skin epithelium by induction of $\beta$-defensin 2 via TLR2 and TLR4. J Immunol. (2008) 181:2103-10. doi: 10.4049/jimmunol.181. 3.2103

50. Bayer A, Lammel J, Tohidnezhad M, Lippross S, Behrendt P, Klüter T, et al. The antimicrobial peptide human $\beta$-defensin- 3 is induced by plateletreleased growth factors in primary keratinocytes. Mediators Inflamm. (2017) 2017:6157491. doi: 10.1155/2017/6157491

51. Carter JG, West SK, Painter S, Haynes RJ, Churchill AJ. $\beta$-defensin 1 haplotype associated with postoperative endophthalmitis. Acta Ophthalmol. (2010) 88:786-90. doi: 10.1111/j.1755-3768.2009.01534.x

52. Dybdahl B, Wahba A, Lien E, Flo TH, Waage A, Qureshi N, et al. Inflammatory response after open heart surgery: release of heat-shock protein 70 and signaling through toll-like receptor-4. Circulation. (2002) 105:685-90. doi: 10.1161/hc0602.103617

53. Vacas S, Degos V, Tracey KJ, Maze M. High-mobility group box 1 protein initiates postoperative cognitive decline by engaging bone marrow-derived macrophages. Anesthesiology. (2014) 120:1160-7. doi: 10.1097/ALN.0000000000000045

54. Mollen KP, Prince JM, Billiar TR, Liu S, Kaczorowski DJ, Hackam DJ, et al. Systemic inflammation and remote organ injury following trauma require HMGB1. Am J Physiol Integr Comp Physiol. (2007) 293:R153844. doi: 10.1152 /ajpregu. 00272.2007
55. Dusio GF, Cardani D, Zanobbio L, Mantovani M, Luchini P, Battini L, et al. Stimulation of TLRs by LMW-HA induces self-defense mechanisms in vaginal epithelium. Immunol Cell Biol. (2011) 89:630-9. doi: 10.1038/icb.2010.140

56. Zhang J, Wang H, Xiao Q, Liang H, Li Z, Jiang C, et al. Hyaluronic acid fragments evoke Kupffer cells via TLR4 signaling pathway. Sci China Ser C Life Sci. (2009) 52:147-54. doi: 10.1007/s11427-009-0002-y

57. Vabulas RM, Ahmad-Nejad P, Ghose S, Kirschning CJ, Issels RD, Wagner H. HSP70 as endogenous stimulus of the toll/interleukin-1 receptor signal pathway. J Biol Chem. (2002) 277:15107-12. doi: 10.1074/jbc.M11 1204200

58. Okamura Y, Watari M, Jerud ES, Young DW, Ishizaka ST, Rose J, et al. The extra domain a of fibronectin activates toll-like receptor 4. J Biol Chem. (2001) 276:10229-33. doi: 10.1074/jbc.M100099200

59. Tschopp J, Schroder K. NLRP3 inflammasome activation: the convergence of multiple signalling pathways on ROS production? Nat Rev Immunol. (2010) 10:210-5. doi: 10.1038/nri2725

60. Guarda G, Zenger M, Yazdi AS, Schroder K, Ferrero I, Menu P, et al. Differential expression of NLRP3 among hematopoietic cells. J Immunol. (2011) 186:2529-34. doi: 10.4049/jimmunol.1002720

61. Zhang A, Wang K, Ding L, Bao X, Wang X, Qiu X, et al. Bay11-7082 attenuates neuropathic pain via inhibition of nuclear factor-kappa $B$ and nucleotide-binding domain-like receptor protein 3 inflammasome activation in dorsal root ganglions in a rat model of lumbar disc herniation. J Pain Res. (2017) 10:375-82. doi: 10.2147/JPR.S119820

62. Fann DY-W, Lim Y-A, Cheng Y-L, Lok K-Z, Chunduri P, Baik S-H, et al. Evidence that NF- $\mathrm{KB}$ and MAPK signaling promotes NLRP inflammasome activation in neurons following ischemic stroke. Mol Neurobiol. (2017) 55:1082-96. doi: 10.1007/s12035-017-0394-9

63. He Y, Hara $H$, Nunez G. Mechanism and regulation of NLRP3 inflammasome activation. Trends Biochem Sci. (2016) 41:1012-21. doi: 10.1016/j.tibs.2016.09.002

64. Schroder K, Tschopp J. The Inflammasomes. Cell. (2010) 140:82132. doi: 10.1016/j.cell.2010.01.040

65. Martinon F, Burns K, Tschopp J. The inflammasome. Mol Cell. (2002) 10:417-26. doi: 10.1016/S1097-2765(02)00599-3

66. Tsuda M, Koizumi S, Inoue K. Role of endogenous ATP at the incision area in a rat model of postoperative pain. Neuroreport. (2001) 12:17014. doi: 10.1097/00001756-200106130-00036

67. Riteau N, Baron L, Villeret B, Guillou N, Savigny F, Ryffel B, et al. ATP release and purinergic signaling: a common pathway for particle-mediated inflammasome activation. Cell Death Dis. (2012) 3:e403. doi: 10.1038/cddis.2012.144

68. Sugiyama D, Kang S, Brennan TJ. Muscle reactive oxygen species (ROS) contribute to post-incisional guarding via the TRPA1 receptor. PLoS ONE. (2017) 12:e0170410. doi: 10.1371/journal.pone.0170410

69. Dai J, Zhang X, Wang Y, Chen H, Chai Y. ROS-activated NLRP3 inflammasome initiates inflammation in delayed wound healing in diabetic rats. Int J Clin Exp Pathol. (2017) 10:9902-9.

70. Woo YC, Park SS, Subieta AR, Brennan TJ. Changes in tissue $\mathrm{pH}$ and temperature after incision indicate acidosis may contribute to postoperative pain. Anesthesiology. (2004) 101:468-75. doi: 10.1097/00000542-200408000-00029

71. Rajamäki K, Nordström T, Nurmi K, Åkerman KEO, Kovanen PT, Öörni $\mathrm{K}$, et al. Extracellular acidosis is a novel danger signal alerting innate immunity via the NLRP3 inflammasome. J Biol Chem. (2013) 288:134109. doi: $10.1074 /$ jbc.M112.426254

72. Takenouchi $\mathrm{T}$, Tsukimoto $\mathrm{M}$, Hashimoto $\mathrm{M}$, Kitani H. Inflammasome activation by danger signals: extracellular ATP and $\mathrm{pH}$. Inflammasome. (2014) 1:76-80. doi: 10.2478/infl-2014-0008

73. Sorge RE, Mapplebeck JCS, Rosen S, Beggs S, Taves S, Alexander JK, et al. Different immune cells mediate mechanical pain hypersensitivity in male and female mice. Nat Neurosci. (2015) 18:1081-3. doi: 10.1038/ nn. 4053

74. Sorge RE, Lacroix-fralish ML, Tuttle AH, Sotocinal SG, Austin J, Ritchie J, et al. Spinal cord Toll-like receptor 4 mediates inflammatory and neuropathic hypersensitivity in male but not female mice. J Neurosci. (2011) 31:154504. doi: 10.1523/JNEUROSCI.3859-11.2011 
75. Jaillon S, Berthenet K, Garlanda C. Sexual dimorphism in innate immunity. Clin Rev Allergy Immunol. (2017). doi: 10.1007/s12016-017-8648-x. [Epub ahead of print].

76. Klein SL, Marriott I, Fish EN. Sex-based differences in immune function and responses to vaccination. Trans R Soc Trop Med Hyg. (2015) 109:915. doi: 10.1093/trstmh/tru167

77. Atkins PC, von Allman C, Valenzano M, Zweiman B. The effects of gender on allergen-induced histamine release in ongoing allergic cutaneous reactions. J Allergy Clin Immunol. (1993) 91:1031-4. doi: 10.1016/0091-6749(93) 90216-3

78. Bird MD, Karavitis J, Kovacs EJ. Sex differences and estrogen modulation of the cellular immune response after injury. Cell Immunol. (2008) 252:5767. doi: 10.1016/j.cellimm.2007.09.007

79. Herneisey M, Mejia G, Pradhan G, Dussor G, Price T, Janjic J. Resveratrol nanoemulsions target inflammatory macrophages to prevent. J Pain. (2018) 19:S75-6. doi: 10.1016/j.jpain.2017.12.173

80. Cheng $\mathrm{C}$, Wu H, Wang M, Wang L, Zou H, Li S, et al. Estrogen ameliorates allergic airway inflammation via regulating the activation of NLRP3 inflammasome in mice. Biosci Rep. (2018) 39:BSR20181117. doi: 10.1042/BSR20181117

81. Keselman A, Fang X, White PB, Heller NM. Estrogen signaling contributes to sex differences in macrophage polarization during asthma. J Immunol. (2017) 199:1573-83. doi: 10.4049/jimmunol.1601975

82. Martinez FO, Gordon S. The M1 and M2 paradigm of macrophage activation: time for reassessment. F1000Prime Rep. (2014) 6:1-13. doi: 10.12703/P6-13

83. Zendedel A, Mönnink F, Hassanzadeh G, Zaminy A, Ansar MM, Habib P, et al. Estrogen attenuates local inflammasome expression and activation after spinal cord injury. Mol Neurobiol. (2018) 55:136475. doi: 10.1007/s12035-017-0400-2

84. Calippe B, Douin-Echinard V, Delpy L, Laffargue M, Lélu K, Krust A, et al. $17 \beta$-estradiol promotes TLR4-triggered proinflammatory mediator production through direct estrogen receptor $\alpha$ signaling in macrophages in vivo. J Immunol. (2010) 185:1169-76. doi: 10.4049/jimmunol.0902383

85. Yang C-A, Huang S-T, Chiang BL. Sex-dependent differential activation of NLRP3 and AIM2 inflammasomes in SLE macrophages. Rheumatology. (2015) 54:324-31. doi: 10.1093/rheumatology/keu318

86. Burton M, Szabo-Pardi T, Garner K, Tierney J, Price T. Uncovering cellspecific mechanisms in sex differences in TLR4-dependent pain. J Pain. (2019) 20:S1. doi: 10.1016/j.jpain.2019.01.016

87. Burton M, Szabo-Pardi T, Garner K, Asiedu M, Mejia G, Megat S, et al. (131) TLR4-dependent pain depends on different cell types in males and females. $J$ Pain. (2017) 18:S9. doi: 10.1016/j.jpain.2017.02.037

88. Ganesan K, Balachandran C, Manohar BM, Puvanakrishnan R. Effects of testosterone, estrogen and progesterone on TNF- $\alpha$ mediated cellular damage in rat arthritic synovial fibroblasts. Rheumatol Int. (2012) 32:31818. doi: 10.1007/s00296-011-2146-x

89. Dinarello CA. Immunological and inflammatory functions of the interleukin-1 family. Annu Rev Immunol. (2009) 27:51950. doi: 10.1146/annurev.immunol.021908.132612

90. Copray JCVM, Mantingh I, Brouwer N, Biber K, Küst BM, Liem RSB, et al. Expression of interleukin-1 $\beta$ in rat dorsal root ganglia. J Neuroimmunol. (2001) 118:203-11. doi: 10.1016/S0165-5728(01)00324-1

91. Verri WA, Cunha TM, Parada CA, Poole S, Cunha FQ, Ferreira SH. Hypernociceptive role of cytokines and chemokines: targets for analgesic drug development? Pharmacol Ther. (2006) 112:116-38. doi: 10.1016/j.pharmthera.2006.04.001

92. Hou L, Li W, Wang X. Mechanism of interleukin-1 $\beta$-induced calcitonin gene-related peptide production from dorsal root ganglion neurons of neonatal rats. J Neurosci Res. (2003) 73:188-97. doi: 10.1002/jnr.10651

93. Jura J, Wegrzyn P, Korostynski M, Guzik K, Oczko-Wojciechowska M, Jarzab $\mathrm{M}$, et al. Identification of interleukin-1 and interleukin-6-responsive genes in human monocyte-derived macrophages using microarrays. Biochim Biophys Acta. (2008) 1779:383-89. doi: 10.1016/j.bbagrm.2008.04.006

94. Weber $\mathrm{A}$, Wasiliew $\mathrm{P}$, Kracht $\mathrm{M}$. Interleukin-1 $\beta$ (IL-1 $\beta$ ) processing pathway. Sci Signal. (2010) 3:cm2. doi: 10.1126/scisignal.3105 $\mathrm{cm} 2$

95. Boraschi D, Tagliabue A. The interleukin-1 receptor family. Semin Immunol. (2013) 25:394-407. doi: 10.1016/j.smim.2013.10.023
96. Song A, Zhu L, Gorantla G, Berdysz O, Amici SA, Guerau-de-Arellano M, et al. Salient type 1 interleukin 1 receptor expression in peripheral non-immune cells. Sci Rep. (2018) 8:1-14. doi: 10.1038/s41598-018-19248-7

97. Weber A, Wasiliew P, Kracht M. Interleukin-1 (IL-1) pathway. Sci Signal. (2010) 3:cm1. doi: 10.1126/scisignal.3105 cm1

98. Chen $\mathrm{H}$, Jiang YS, Sun Y, Xiong YC. P38 and interleukin-1 $\beta$ pathway via toll-like receptor 4 contributed to the skin and muscle incision and retraction-induced allodynia. J Surg Res. (2015) 197:33947. doi: 10.1016/j.jss.2015.04.061

99. Spofford CM, Brennan TJ. Gene expression in skin, muscle, and dorsal root ganglion after plantar incision in the rat. Anesthesiology. (2012) 117:16172. doi: 10.1097/ALN.0b013e31825a2a2b

100. Loram LC, Themistocleous AC, Fick LG, Kamerman PR. The time course of inflammatory cytokine secretion in a rat model of postoperative pain does not coincide with the onset of mechanical hyperalgesia. Can J Physiol Pharmacol. (2007) 85:613-20. doi: 10.1139/Y07-054

101. Liang D, Shi X, Qiao Y, Angst MS, Yeomans DC, Clark JD. Chronic morphine administration enhances nociceptive sensitivity and local cytokine production after incision. Mol Pain. (2008) 4:7. doi: 10.1186/1744-8069-4-7

102. Wolf G, Livshits D, Beilin B, Yirmiya R, Shavit Y. Interleukin-1 signaling is required for induction and maintenance of postoperative incisional pain: genetic and pharmacological studies in mice. Brain Behav Immun. (2008) 22:1072-7. doi: 10.1016/j.bbi.2008.03.005

103. Xing F, Zhang W, Wen J, Bai L, Gu H, Li Z, et al. TLR4/NF$\kappa \mathrm{B}$ signaling activation in plantar tissue and dorsal root ganglion involves in the development of postoperative pain. Mol Pain. (2018) 14:1744806918807050. doi: 10.1177/1744806918807050

104. Liang D-Y, Li X, Li W-W, Fiorino D, Qiao Y, Sahbaie P, et al. Caspase-1 modulates incisional sensitization and inflammation. Anesthesiology. (2010) 113:945-56. doi: 10.1097/ALN.0b013e3181ee2f17

105. Cabral VP, de Andrade CAF, Passos SRL, Martins M de FM, Hökerberg YHM. Severe infection in patients with rheumatoid arthritis taking anakinra, rituximab, or abatacept: a systematic review of observational studies. Rev Bras Reumatol. (2016) 56:543-50. doi: 10.1016/j.rbre.2016. 10.001

106. Sahoo M, Ceballos-Olvera I, Del Barrio L, Re F. Role of the inflammasome, IL-1 $\beta$, and IL-18 in bacterial infections. Sci World J. (2011) 11:203750. doi: $10.1100 / 2011 / 212680$

107. Van Gulik L, Janssen LI, Ahlers SJGM, Bruins P, Driessen AHG, Van Boven WJ, et al. Risk factors for chronic thoracic pain after cardiac surgery via sternotomy. Eur J Cardio Thor Surg. (2011) 40:130913. doi: 10.1016/j.ejcts.2011.03.039

108. Caumo W, Schmidt AP, Schneider CN, Bergmann J, Iwamoto CW, Adamatti LC, et al. Preoperative predictors of moderate to intense acute postoperative pain in patients undergoing abdominal surgery. Acta Anaesthesiol Scand. (2002) 46:1265-71. doi: 10.1034/j.1399-6576.2002.46 1015.x

109. Katz J, Poleshuck EL, Andruse CH, Hogan LA, Jung BF, Kulick DI, et al. Risk factors for acute pain and its persistence following breast cancer surgery. Pain. (2005) 119:16-25. doi: 10.1016/j.pain.2005.09.008

110. Braddock M, Quinn A. Targeting IL-1 in inflammatory disease: new opportunities for therapeutic intervention. Nat Rev Drug Discov. (2004) 3:330-40. doi: $10.1038 /$ nrd1342

111. Pillarisetti S. Targeting interleukin-1b for pain. CNS Neurol Disord Drug Targets. (2011) 10:571-5. doi: 10.2174/187152711796234998

112. Vande Walle L, Van Opdenbosch N, Jacques P, Fossoul A, Verheugen E, Vogel P, et al. Negative regulation of the NLRP3 inflammasome by A20 protects against arthritis. Nature. (2014) 512:69-73. doi: 10.1038/nature13322

113. Choulaki C, Papadaki G, Repa A, Kampouraki E, Kambas K, Ritis K, et al. Enhanced activity of NLRP3 inflammasome in peripheral blood cells of patients with active rheumatoid arthritis. Arthritis Res Ther. (2015) 17:111. doi: 10.1186/s13075-015-0775-2

114. Martinon F, Pétrilli V, Mayor A, Tardivel A, Tschopp J. Gout-associated uric acid crystals activate the NALP3 inflammasome. Nature. (2006) 440:23741. doi: 10.1038/nature04516

115. Hoffman HM, Scott P, Mueller JL, Misaghi A, Stevens S, Yancopoulos GD, et al. Role of the leucine-rich repeat (LRR) domain of cryopyrin/ NALP3 
in monosodium urate crystal-induced inflammation. Arthritis Rheumatol. (2010) 62:2170-9. doi: 10.1002/art.27456

116. Amaral FA, Costa VV, Tavares LD, Sachs D, Coelho FM, Fagundes CT, et al. NLRP3 inflammasome-mediated neutrophil recruitment and hypernociception depend on leukotriene B4 in a murine model of gout. Arthritis Rheum. (2012) 64:474-84. doi: 10.1002/art.33355

117. Garcia MA, Daemen MA, Steinbusch HW, Visser-Vandewalle V, Andrade P, Hoogland G. Elevated IL-1 $\beta$ and IL-6 levels in lumbar herniated discs in patients with sciatic pain. Eur Spine J. (2013) 22:714-20. doi: 10.1007/s00586-012-2502-x

118. Thacker MA, Clark AK, Marchand F, McMahon SB. Pathophysiology of peripheral neuropathic pain: immune cells and molecules. Anesth Analg. (2007) 105:838-47. doi: 10.1213/01.ane.0000275190.42 912.37

119. Gui W-S, Wei X, Mai C-L, Murugan M, Wu L-J, Xin W-J, et al. Interleukin- $1 \beta$ overproduction is a common cause for neuropathic pain, memory deficit, and depression following peripheral nerve injury in rodents. Mol Pain. (2016) 12:1-15. doi: 10.1177/17448069166 46784

120. Curto-Reyes V, Kirschmann G, Pertin M, Drexler SK, Decosterd I, Suter MR. Neuropathic pain phenotype does not involve the NLRP3 inflammasome and its end product interleukin- $1 \beta$ in the Mice spared nerve injury model. PLoS ONE. (2015) 10:e0133707. doi: 10.1371/journal.pone.01 33707

121. Denk F, Crow M, Didangelos A, Lopes DM, McMahon SB. Persistent alterations in microglial enhancers in a model of chronic pain. Cell Rep. (2016) 15:1771-81. doi: 10.1016/j.celrep.2016.04.063

122. Peng J, Gu N, Zhou L, Eyo BU, Murugan M, Gan WB, et al. Microglia and monocytes synergistically promote the transition from acute to chronic pain after nerve injury. Nat Commun. (2016) 7:12029. doi: 10.1038/ncomms12029

123. Batti L, Sundukova M, Murana E, Pimpinella S, De Castro Reis F, Pagani F, et al. TMEM16F regulates spinal microglial function in neuropathic pain states. Cell Rep. (2016) 15:2608-15. doi: 10.1016/j.celrep.2016.05.039

Conflict of Interest Statement: The authors declare that the research was conducted in the absence of any commercial or financial relationships that could be construed as a potential conflict of interest.

Copyright $\odot 2019$ Cowie, Dittel and Stucky. This is an open-access article distributed under the terms of the Creative Commons Attribution License (CC BY). The use, distribution or reproduction in other forums is permitted, provided the original author(s) and the copyright owner(s) are credited and that the original publication in this journal is cited, in accordance with accepted academic practice. No use, distribution or reproduction is permitted which does not comply with these terms. 